\title{
UC Cooperative Extension works with fire safe councils to reduce wildfires
}

\author{
by Glenn A. Nader and Michael De Lasaux
}

\begin{abstract}
In Plumas, Butte and Yuba counties, UC Cooperative Extension advisors have collaborated with fire safe councils to mitigate the risk of wildfire in local communities. They have determined the educational needs within the communities, obtained grant funding and worked collaboratively with the councils to deliver education and applied research programs that have helped homeowners and landowners take action to reduce their vulnerability to the risk of wildfires. Home structures have been modified to improve their fire resistance, fuel reduction programs have been adopted by local communities and maintained, communities have been mapped for evacuation plans and fuel breaks have been constructed on private and public forestland. Several wildfires, including the Marysville fire in 2006 and the Yuba fire in 2009, were slowed or stopped because of measures taken, showing the value of investment in pre-fire planning and actions.
\end{abstract}

$\mathrm{F}$ ire safe councils are communitybased organizations that share the objective of making California's communities less vulnerable to wildfire. They are comprised of a collaborative group of local stakeholders, including federal land managers, state and local fire agency representatives, private forest landowners and community members. They generally meet monthly and work to reduce wildfire hazard through community education programs and fuel reduction projects. Fire safe councils have formed throughout California since the early 1990s and now number more than 100. In Plumas, Butte and Yuba counties, UC Cooperative Extension (UCCE) advisors have worked with local fire safe councils for many years. They have helped to identify needs for science-based information on topics critical to fire risk reduction and delivered the information to the communities in a variety of formats to engage homeowners and landowners in effective pre-fire actions.

\section{Statewide programs}

Many homeowners do not know which components of their home are at risk to fire. Deck, roof and siding materials perform differently when exposed to embers and flames. UCCE Advisor Steve Quarles developed research on this topic and educational information for homeowners (Quarles and Beall 2002). In 2005, Quarles and other UCCE advisors and specialists, as members of the UCCE Fire Workgroup, developed a Renewable

Resources Extension Act proposal and obtained funding to demonstrate how various structural elements can cause a home to be susceptible to fire and how appropriate modification can improve its resilience. Workgroup members developed model wall and deck units for use in demonstration burns to illustrate common construction assembly weaknesses and possible modifications. In collaboration with local fire safe councils, UCCE used the model in a demonstration burn at several community workshops. In 2006, after being trained by Quarles, UCCE Advisor Glenn Nader (one of the authors of this article) conducted a building burning demonstration for the Yuba County

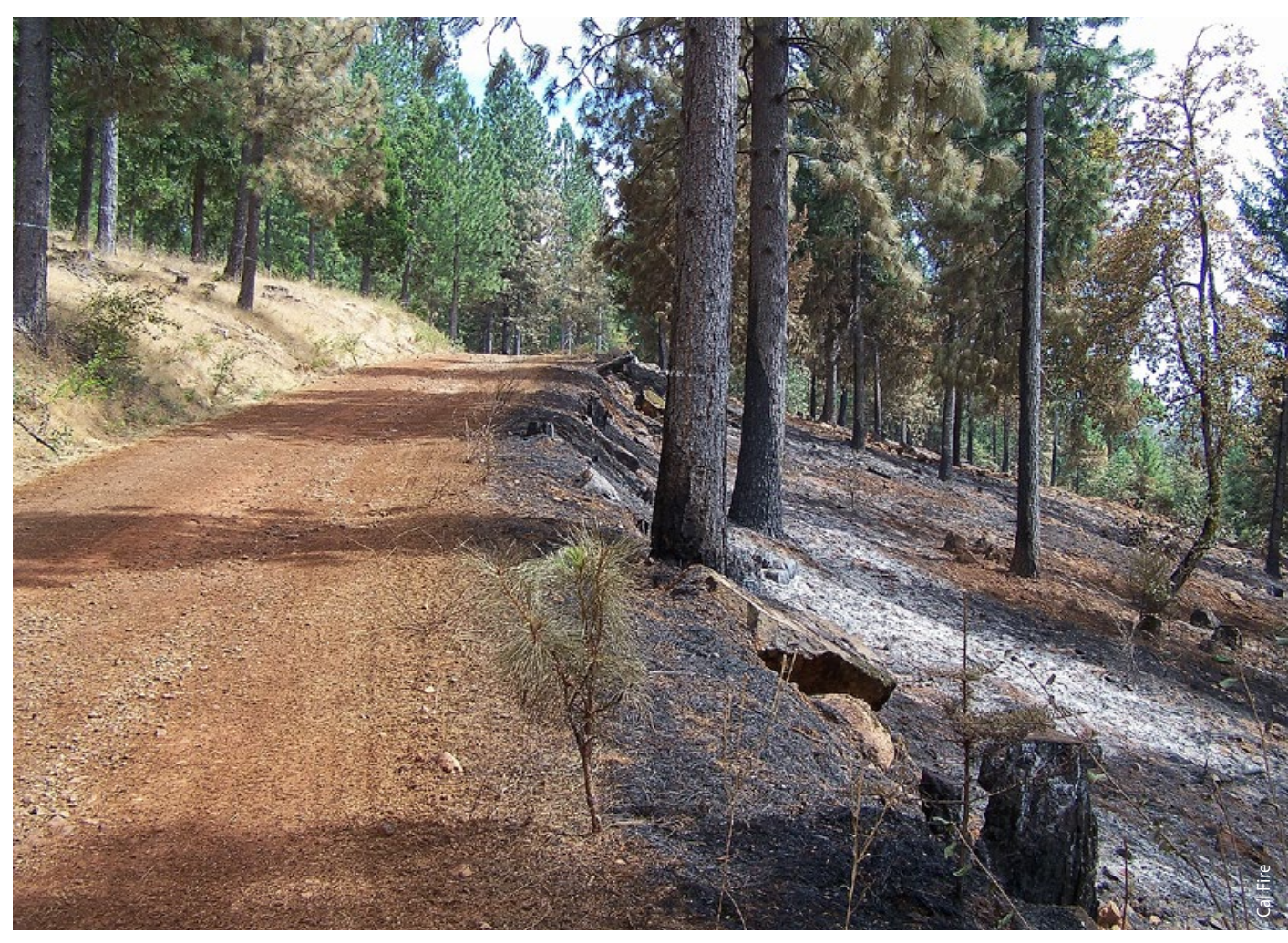

In 2006, a fire in Marysville (Yuba County) was stopped at the Oregon Ridge fuel break, which was constructed by private timber landowners as part of the Slapjack fuel reduction project. 
board of supervisors, which assisted in the creation of the Yuba County fire planner position.

UCCE advisors also developed the UC Agriculture and Natural Resources electronic publication Home Survival in Wildfire-Prone Areas (Quarles et al. 2010), which is used by fire safe councils in their community educational programs with homeowners. Some fire prevention actions are as simple as placing wire screens over vents to keep embers from coming into the house and starting it on fire. Others, such as replacing wood shingle roofing with noncombustible composite or metal roofing, can be expensive.

In 2006, in a collaborative effort with UC Berkeley Professor Scott Stephens, advisors obtained funds from multiple sources, including the Sierra Nevada Conservancy, the California Fire Safe Council Grants Clearinghouse and the Renewable Resources Extension Act for field research into the long-term efficacy of past forest fuel treatments. The fuel

\section{The UCCE Fire Workgroup developed a model home deck unit to demonstrate structural susceptibility to fire and measures to improve fire resistance. Note that the fire has burned through one deck.}

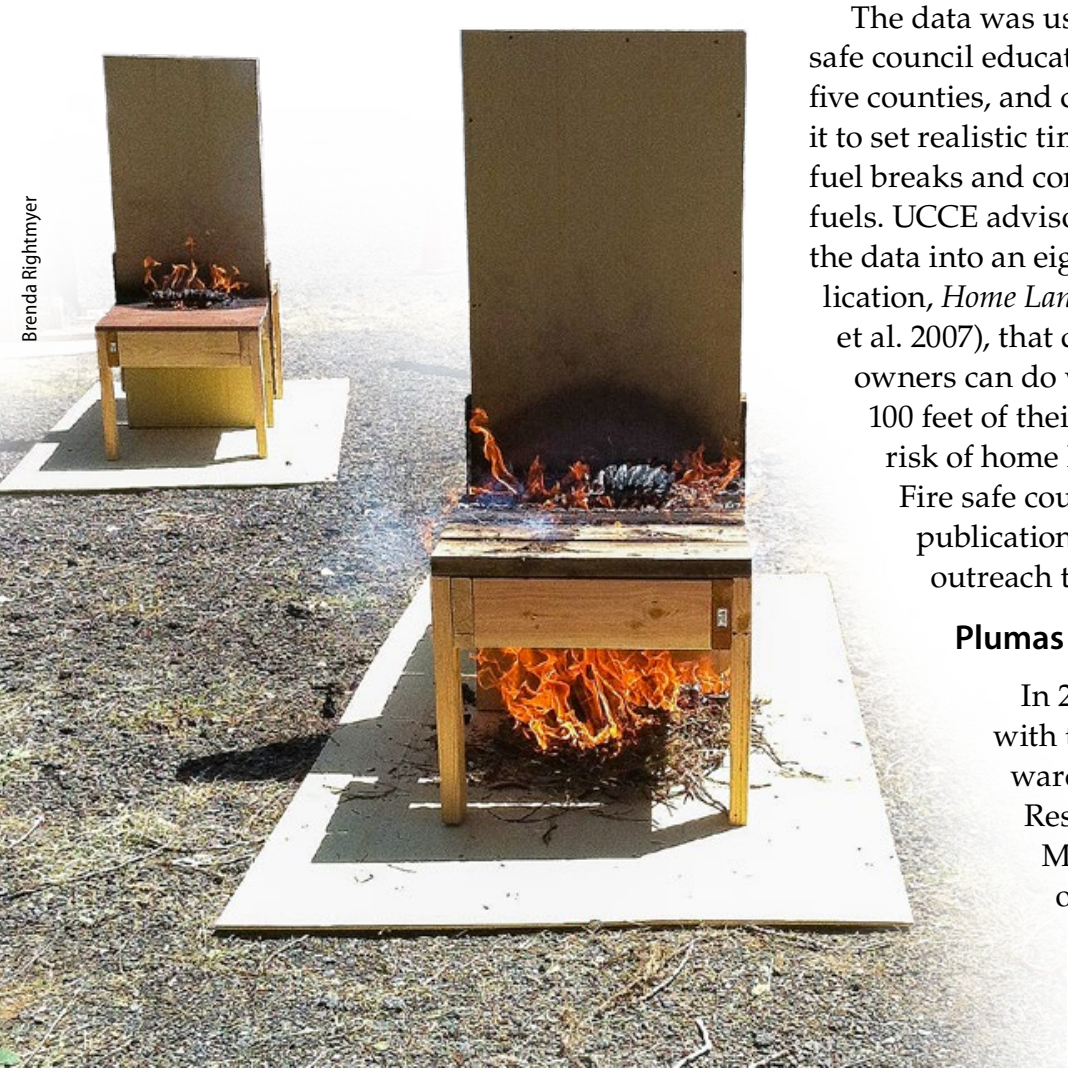

treatment study used a chronosequence of 52 treated fuel reduction sites and 12 nontreated sites in Plumas, Nevada, Sierra, Lassen and Tehama counties (fig. 1). Previously, the lifespan of fuel reduction treatment effects in mixed-conifer and yellow pine forests was estimated to be roughly 10 years.

Figure 2 shows that 8 years and more after fuel reduction, the treatments are still projected by fire models to greatly reduce the chance of a crown fire compared to untreated forest.

The study findings (Chiono et al. 2012) "suggest that in the forest types characteristic of the northern Sierra Nevada and southern Cascades, treatments for wildfire hazard reduction retain their effectiveness for more than 10-15 years and possibly beyond a quarter century."

The data was used in UCCE-led fire safe council education programs in all five counties, and council members used it to set realistic timelines for monitoring fuel breaks and considering re-treating fuels. UCCE advisors also incorporated the data into an eight-page electronic publication, Home Landscaping for Fire (Nader et al. 2007), that describes what home-

owners can do with vegetation within 100 feet of their home to decrease the risk of home loss during a wildfire.

safe councils have used the publication in their educational

\section{mas County}

In 2001, in collaboration with the Plumas County fire warden, UCCE Natural Resources Advisor Michael De Lasaux (one of the authors of this article) developed the county fire safe council's first grantfunded project.
The $\$ 100,000$ grant from the USDA Forest Service Economic Action Program provided community pre-fire planning and educational firewise consultations and laid a foundation for the council's continuing firewise planning, education and community fuel reduction program.

Firewise planning. Among the earliest accomplishments of the Plumas County Fire Safe Council, which formed in 1998, were efforts to help volunteer fire departments prepare for a wildfire that may threaten their community and require evacuation. Volunteer fire departments are prevalent in rural America, but they are typically challenged to recruit, train and equip their volunteers and rarely are able to conduct fire prevention education programs.

UCCE coordinated several projects in association with the county fire service agencies, including (1) mapping all driveways in the county using global positioning system and geographic information system technology (fig. 3) and (2) planning and developing a map for community evacuation, which involved close collaboration with volunteer fire department chiefs and Plumas County emergency services personnel and also a countywide assessment of the fire hazard for each of the defined communities at risk. The driveway coordinates were used to create map books, which were placed 


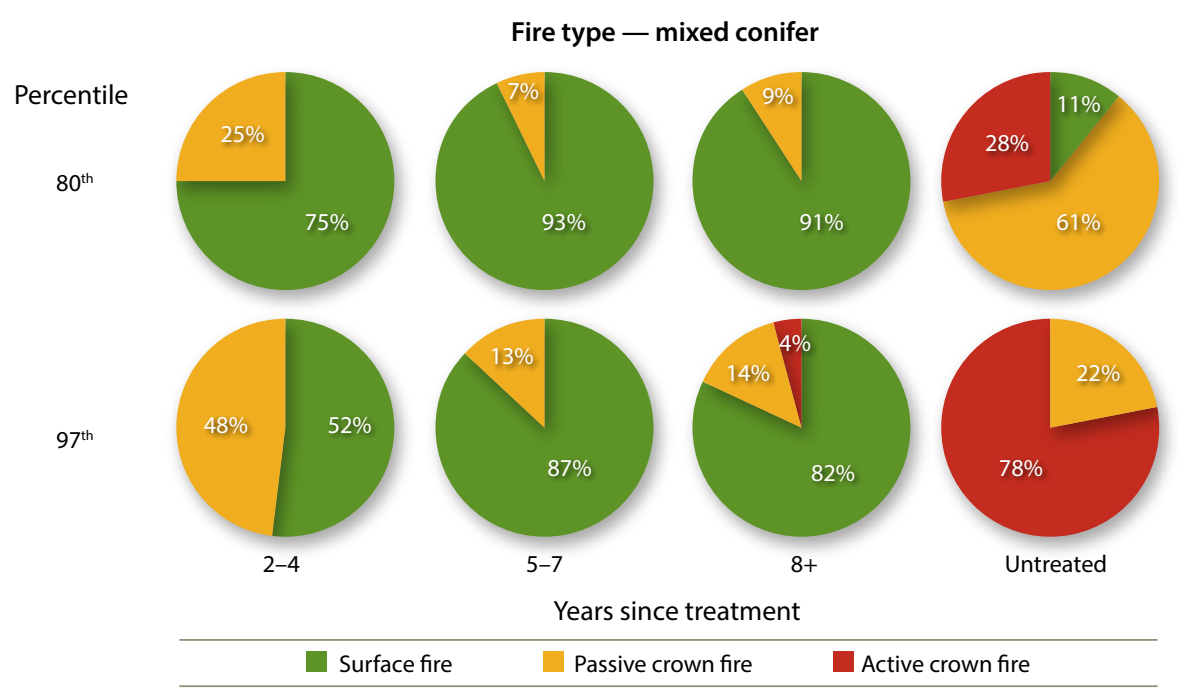

Fig. 2 Fire modeling of fire types on studied fuel reduction treatments. The fire weather index, which is used to predict the risk of weather events causing catastrophic fires, is shown for the 80th and 97th percentiles; the latter is when there is a severe wind event and low moisture levels in the fuels.

in the fire engines of the participating communities. The community fire hazard assessment information has been used in subsequent grant proposals to justify forest fuel reduction treatments in communities at risk.

Firewise education. In 2003, UCCE led the coordination of a series of firewise workshops that focused on communityspecific fire safe planning using the format and resources developed by the National Fire Protection Association workshops. More than 50 community

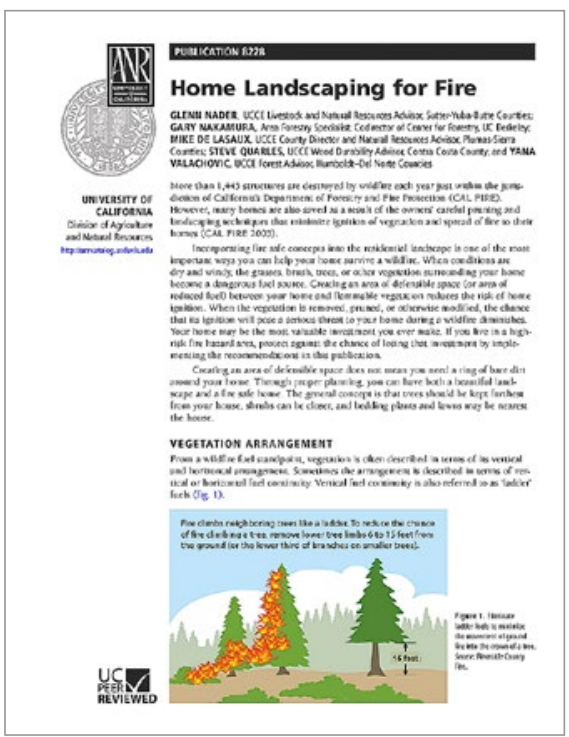

UCCE advisors developed an eight-page electronic publication that helps homeowners manage vegetation within 100 feet of their home and reduce the risk of home loss. members, including county supervisors, volunteer fire department chiefs, realtors and concerned residents participated in these workshops.

Consultations. As part of the 2001 USDA Forest Service Economic Action grant project, De Lasaux coordinated with local fire departments to conduct firewise educational consultations for the public. Volunteer fire departments in six Plumas County communities signed up, and a consultation invitation was sent to nearly 1,700 homeowners, $20 \%$ of whom requested a consultation. A version of the National Fire Protection Association Form 299 (NFPA 1997), which provides criteria for fire safe development in areas that may be threatened by wildfire, was modified to suit local conditions and used to guide consultations. About $20 \%$ of the properties that were assessed during the homeowner consultations were determined to be a high fire hazard.

Newspaper tabloids. The county fire safe council determined that they would like to provide educational information to the widest audience possible, so a tabloid was developed collaboratively with Feather Publishing, the local newspaper publisher. UCCE led the effort to create the first two editions in 1999 and 2000, using the Living With Fire: A Guide for the Homeowner educational materials developed by the University of Nevada Cooperative Extension (Smith 1999). Since 2000, there have been additional tabloids developed with reduced UCCE involvement, demonstrating the longterm impact of UCCE's early work on this project.

Community fuel reduction. The Plumas County Fire Safe Council began development of a community fuel reduction program in 2002 with a demonstration project that treated approximately 63 acres on five parcels. The program was developed by council members in collaboration with De Lasaux, who wrote a detailed description of the processes and policies for landowners contemplating participation in a community fuel reduction program. De Lasaux also drafted a white paper that resulted in the California Board of Forestry developing a timber harvest plan exemption for fuel reduction. Since 2002, more than 4,200 acres have been treated in 25 Plumas County communities with the participation of more than 200 property owners (fig. 4). Grant funds from multiple

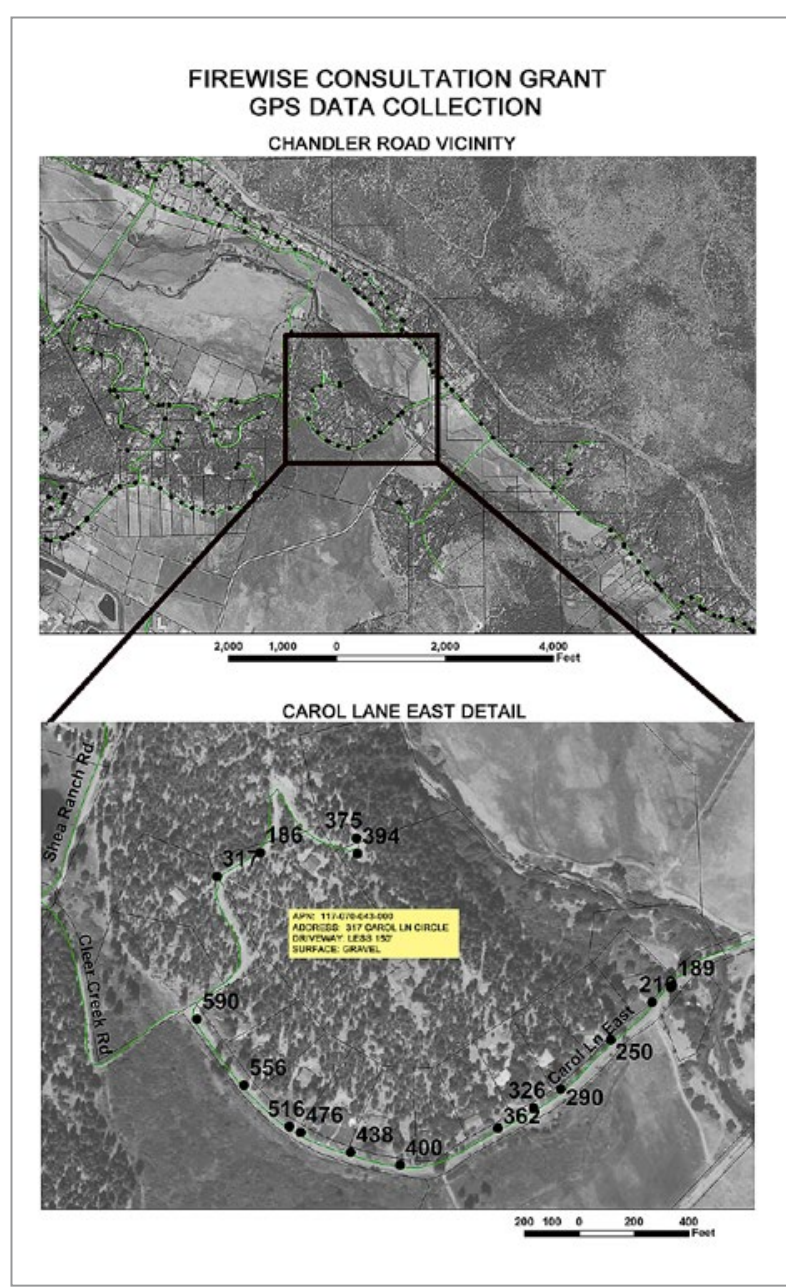

Fig. 3. UCCE coordinated a project to map all driveways in Plumas County using global positioning system and geographic information system technology. Each fire engine in the county has a copy of the map book. 
state and federal sources have totaled more than $\$ 4.4$ million.

De Lasaux monitored more than 70 plots in seven communities to develop information to share with property owners who were considering participation. The plots were assessed before and shortly after fuel reduction treatment. Information collected at each plot included forest stand structure and species composition, canopy cover, surface fuel load, canopy base height, ladder fuel condition and project economics; pre- and post-treatment photographs were also taken.

\section{Butte and Yuba counties}

Fuel reduction maintenance. Advisor Nader obtained a grant to conduct a survey of what motivated homeowners to maintain fuel reduction around their home after they had participated in community fuel reduction projects funded by Yuba Watershed Protection and Fire Safe Council grants. Homeowners who were actively maintaining the fuel reduction were given a list of potential influences to indicate which had an impact on their decision to maintain their property in a firesafe condition. The results (table 1) helped the Yuba and Butte fire safe councils design their fire safe education to obtain higher participation in fuel reduction.

Sixth-grade wildfire education.

Educational efforts that aim to change behavior patterns in society often focus on youth. This approach can also contribute to additive education of parents (Ballard and Evans 2012). Nader used materials from a primary and secondary education

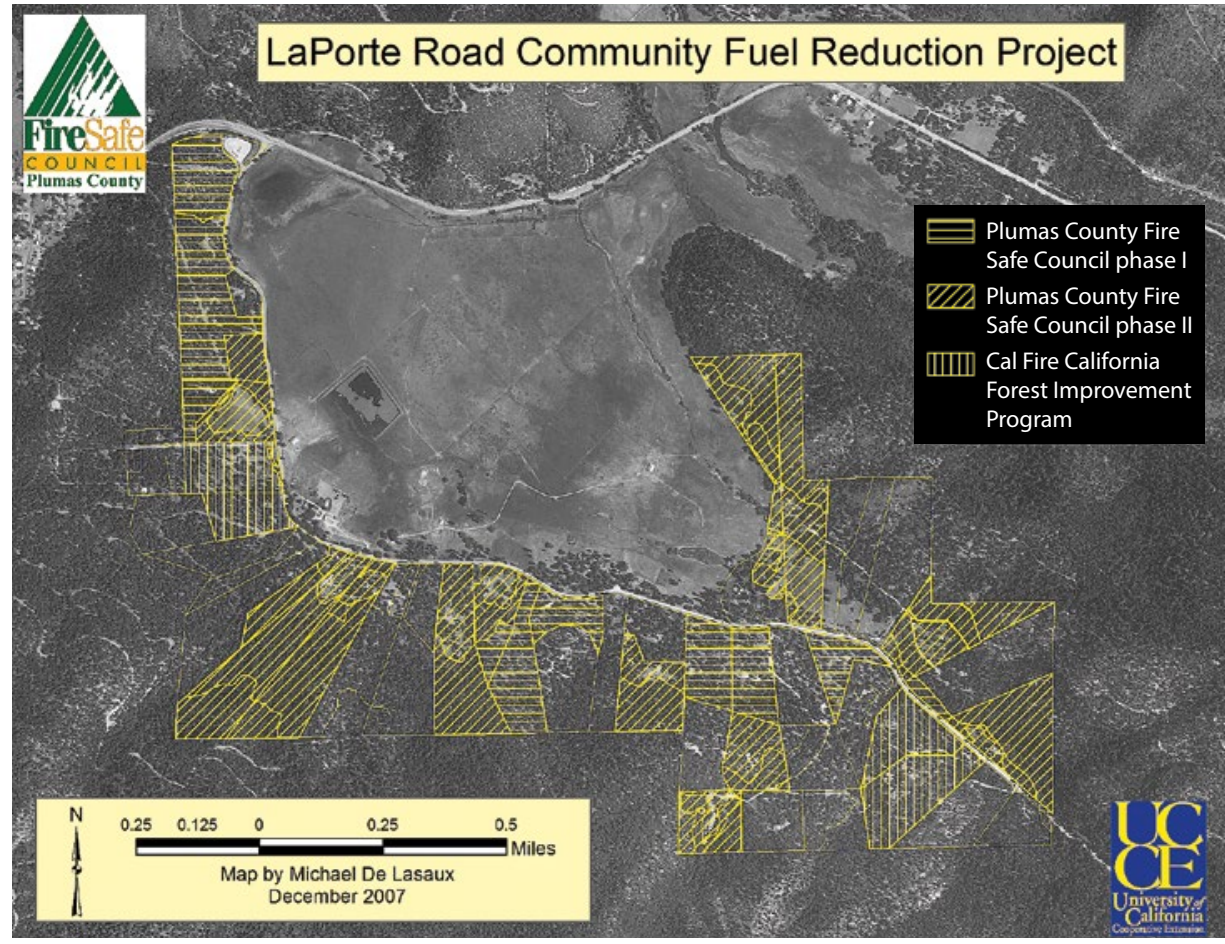

Fig. 4. La Porte Road community fuel reduction map, in Plumas County, showing significant homeowner participation in the project.

course he took called Fire Works at the Missoula Fire Sciences Laboratory in Missoula, Montana, to form the framework of the Butte Fire Safe Council's sixthgrade program, Wildfire in the Foothills.

A grant from the Renewable Resources Extension Act allowed Nader to hire retired teachers to develop a course that addressed state curriculum requirements. It provides teachers with in-service credits and is a complete package that requires no extra preparation work for teachers.
The curriculum uses a teaching method called the three R's (relationships, relevance and rigor) to teach lasting knowledge about wildland fire in five lessons, each of which has a distinct learning concept (table 2).

The 2004 pilot program was very successful, with outreach to 90 sixth-grade students in the Paradise Unified School District, which includes Paradise and Upper Ridge. In 2005, the school district taught the program to 490 sixth-grade
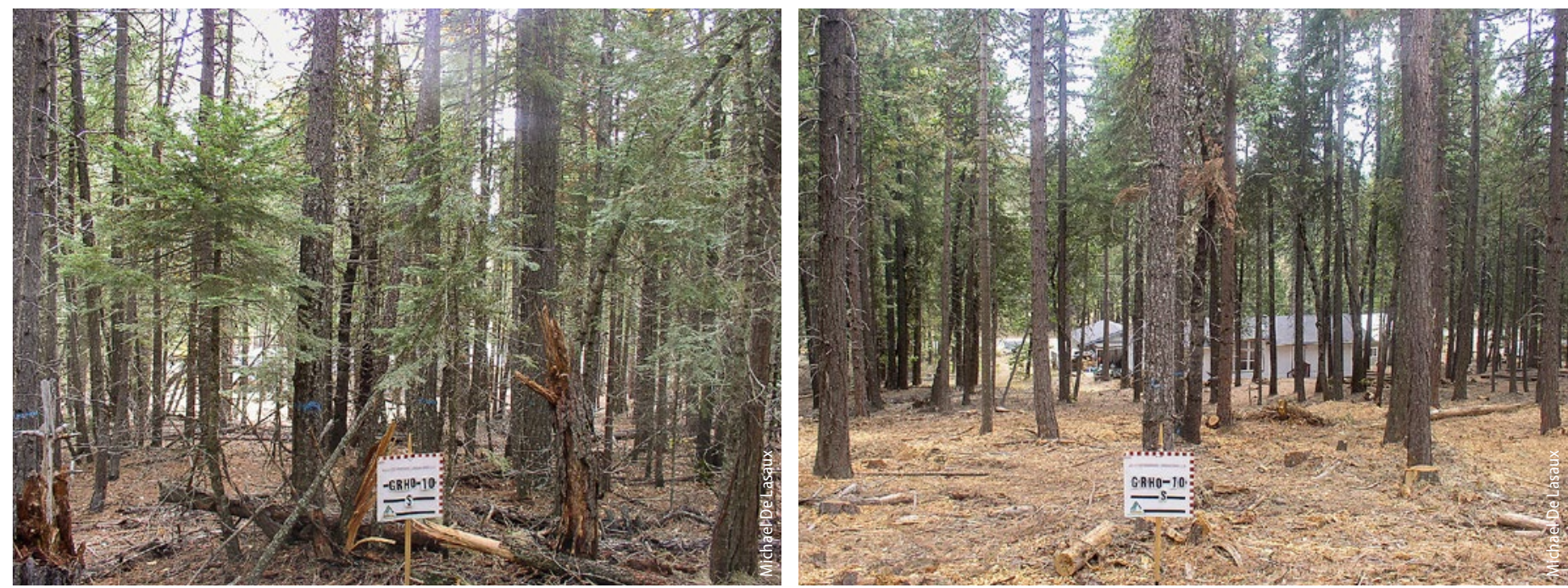

More than 70 plots were monitored in seven Plumas County communities before, left, and after, right, fuel reduction treatments. 


\begin{tabular}{lc}
\multicolumn{2}{c}{$\begin{array}{c}\text { TABLE 1. Homeowner motivations for } \\
\text { maintaining fire-safe conditions }\end{array}$} \\
\hline \hline & $\%$ \\
\hline $\begin{array}{l}\text { Concerned about a wildfire destroying } \\
\text { my home }\end{array}$ & 96 \\
Desire to keep my environment healthy & 93 \\
Recommended by the fire department & 47 \\
Required by my insurance carrier & 31 \\
$\begin{array}{l}\text { Treatment project contract provision to } \\
\text { conduct maintenance }\end{array}$ & 22 \\
Other & 20 \\
Peer pressure from neighbors & 5 \\
\hline
\end{tabular}

students. The program is also being offered to 95 students in the Golden Feather School District.

Wildfire in the Foothills attracted the attention of the U.S. Forest Service, which chose it as one of eight programs in their National Fire Plan study "promoting fireadapted human communities through youth wildfire education programs" (Ballard and Evans 2012). One of the findings noted in their study was "interactions between parents and students were encouraged by requiring parents to sign exercises brought home and by parents knowing that they would be asked to evaluate the program. All teachers agreed that suggesting students talk with their parents about wildfire would garner little response, so requiring parent acknowledgment of take-home assignments was critical. One teacher ... told students that he would be talking to their parents about [the program] at teacher-parent conferences, and felt that this was an additional motivation for students to talk with their families. Having multiple checks on accountability were cited as crucial to promoting interaction between students and their family."

Doom the Broom campaign. Scotch, Spanish and French broom, introduced from the Mediterranean for erosion control and ornamental use, have spread to an estimated 600,000 acres in California (McClintock 1985), which is not only a problem that affects plant habitats but a very serious problem in terms of the intensity of wildfires (Downey 2000). As the plant grows, the inner stems die back, providing a highly flammable fuel.

Control efforts were being made by community groups and individuals with little knowledge of the biology of broom
TABLE 2. Learning concepts presented in the Butte Fire Safe Council's sixth-grade program, Wildfire in the Foothills

Understanding the role of fire in the foothills.

Residents living in the foothills are responsible for reducing fire risks on their own property.

Local, state and national agencies have plans to help residents prepare for a wildland-urban interface fire before it happens; all family members must understand and be ready to use community wildland fire disaster plans.

A family disaster plan is vital to surviving a wildland fire.

Residents, community groups and public agencies all play important roles during planning, surviving and recovering from a wildland fire. plants, which resulted in a high number of projects with limited success. Nader used research information to develop an education program that was integrated into the Butte Fire Safe Council's Doom the Broom campaign. The information was extended through postings on the Web, community meetings and hands-on field training sessions. The key to success is using the right tools at the right time that is, cutting broom plants when they are under water stress in August, which can cause up to $80 \%$ mortality, instead of in the spring, when the plants are not impacted. Since broom seeds can germinate many years after the plants are removed, a list of fire-safe native plants was developed that could be planted to compete with germinating broom plants. After the education, homeowners understood the critical control points of broom control and their efforts were more effective.

\section{Coordinated fire mitigation}

After the 1997 Williams fire burned more than 100 homes in Yuba County, the local supervisor called a meeting and said that a fire safe council needed to be formed to make sure this would never happen again. Nader took the lead in forming and managing the council. In 1998, concerns over wildfires in Butte County brought a group of interested parties together and Nader was named chair of the new council there. Both councils were interested in bringing agencies together to plan fire mitigation across the landscape by consensus, rather than according to each agency's jurisdiction, as had been done in the past.

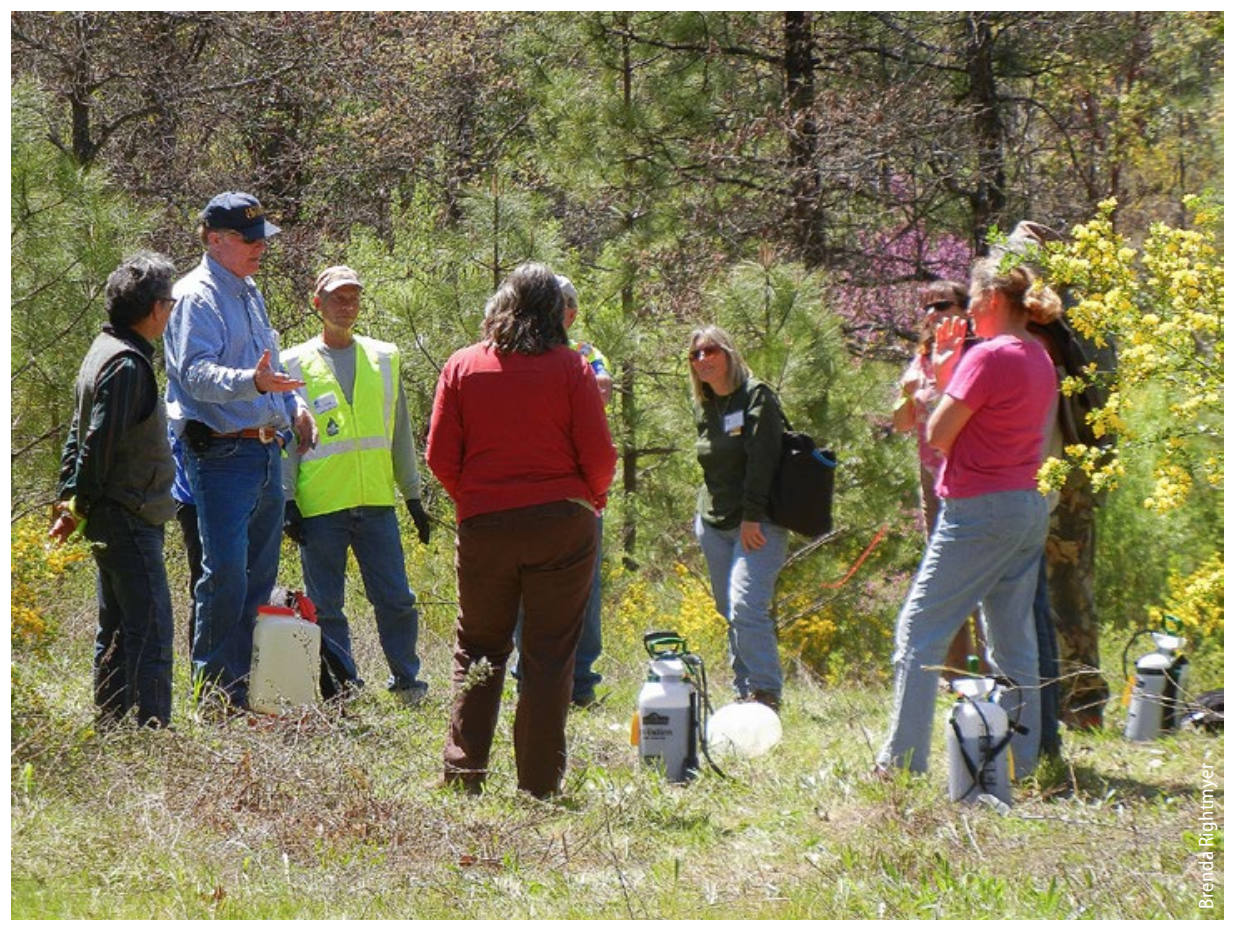

UCCE Advisor Glenn Nader delivers hands-on training to homeowners about the critical points for controlling broom, which is a fire hazard. 


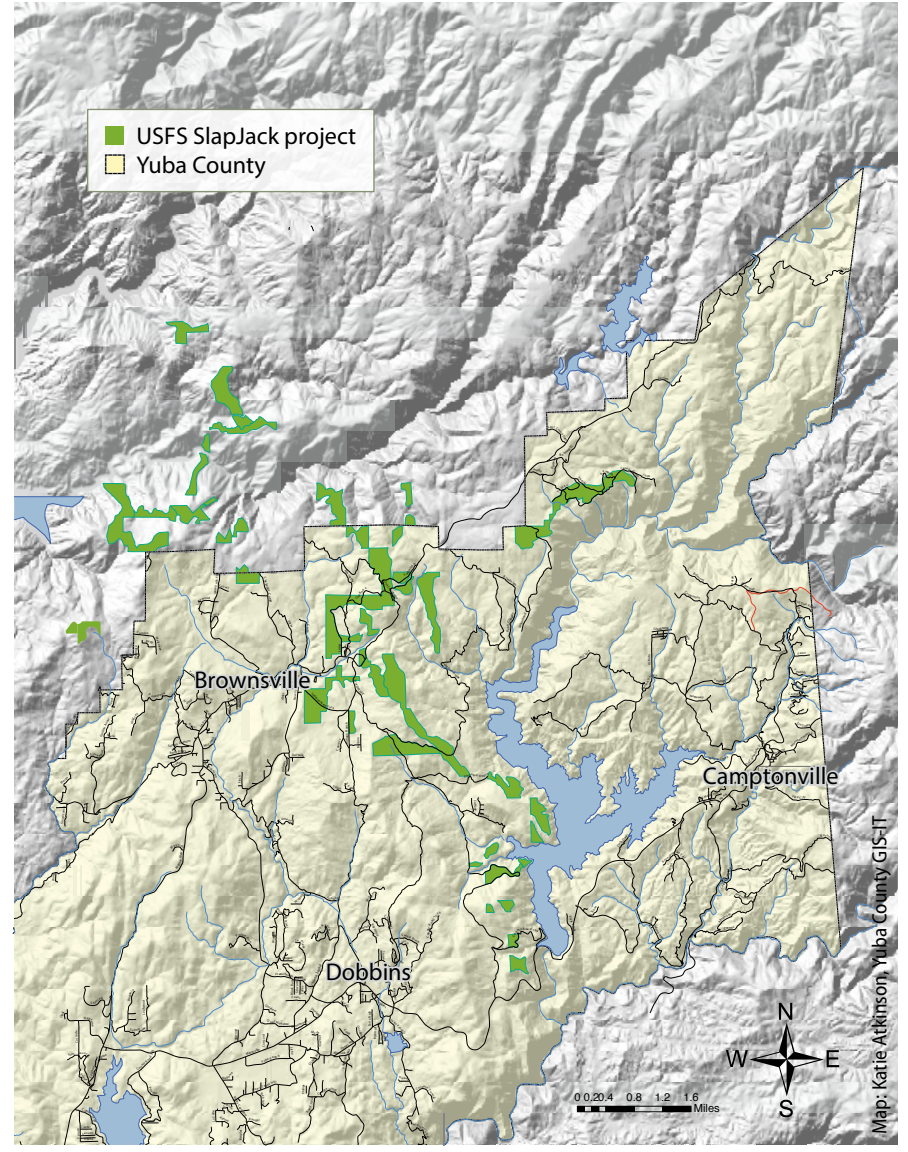

Fig. 5. Map of Slapjack Project, Yuba County.

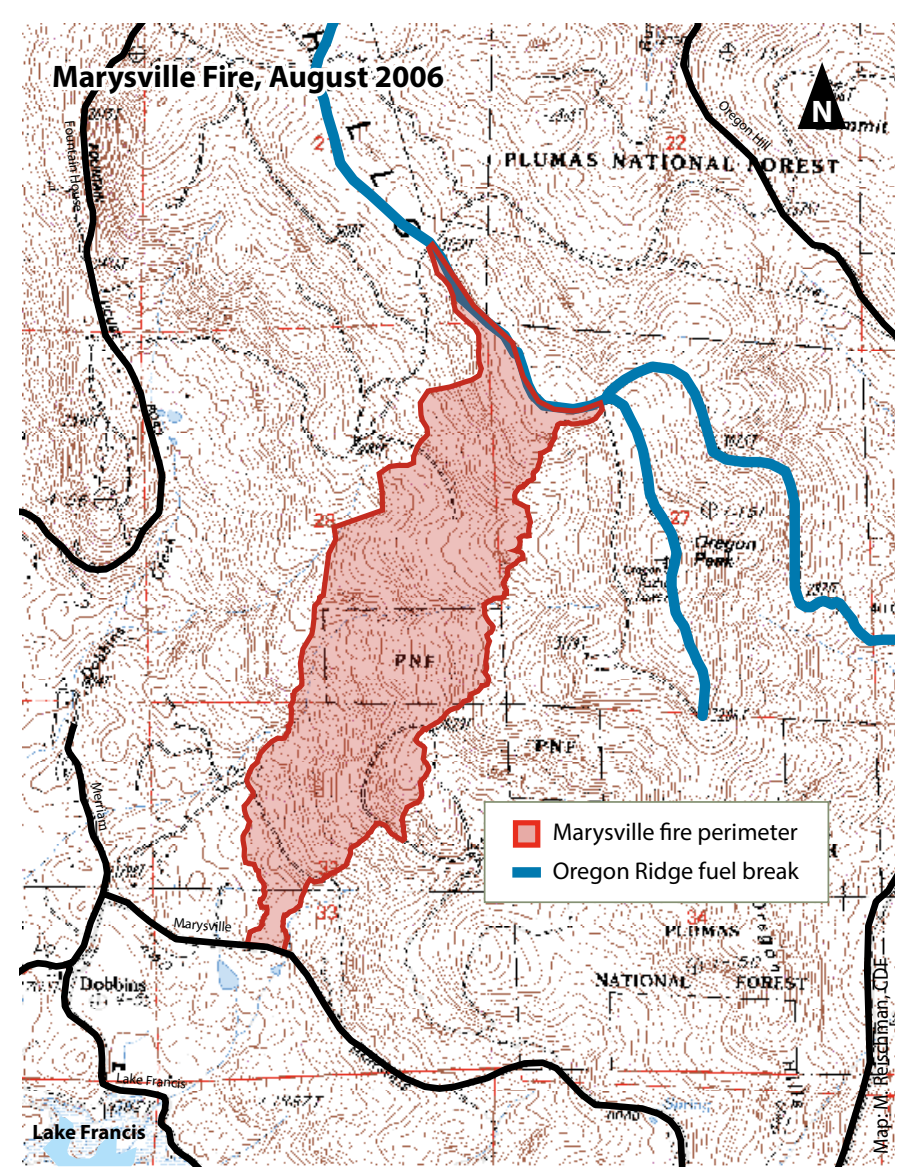

Fig. 6. Map of the Marysville fire.
Nader worked with the Forest Service to form the Slapjack Project in Yuba and Butte counties, which coordinated strategic fuel reduction on 4,419 acres of National Forest, Bureau of Land Management, county and private lands (fig. 5). The Forest Service used Herger Feinstein Quincy Library group funding to implement their portion of the project. De Lasaux provided considerable assistance to the Quincy Library Group as it sought to influence national forest fuel reduction programs. Nader worked with the Yuba Fire Safe Council to obtain \$2.8 million in grants to implement the private and county portions of the project. The Slapjack Project played a key role in preventing two fires from becoming catastrophic.

Marysville fire. One part of Slapjack was the construction of the Oregon Ridge fuel break in Yuba County, which was funded by State Water Resources Board Proposition 204 and featured cooperation among private timber landowners CHY, Soper-Wheeler and Siller Brothers. The Marysville fire, which spread over 442 acres in August 2006 (fig. 6), burned to that fuel break and was stopped there. The fuel break provided a relatively safe place for the firefighters to work; and many trees in the break appear to have survived. In this case, coordinated fire prevention activities helped to limit, or prevent, fire damage to homes, trees and watersheds. It was a testament to sciencebased pre-fire planning with funding for implementation. access road was also constructed. The project was started in 2007 and completed early in 2008.

In August 2009, the Yuba fire consumed 3,891 acres (fig. 7). The fire was slowed down by the south end of the Middlebrook fuel break. If the fire had extended another 500 to 1,000 feet to the north, it would have entered young timber stands, causing considerable economic

\section{The fuel break provided time to marshal firefighting resources. Quick access to the fire was also gained through the new road.}

Yuba fire. A California Department of Forestry and Fire Protection Proposition 40 grant to the Yuba Watershed Protection and Fire Safe Council was used by landowner John Middlebrook to construct a fuel break 300 feet wide for 0.75 mile on his property along Marysville Road and 1.1 miles on the eastern boundary of his property. Brush and small trees were masticated with equipment or hand-cut, piled and burned. A maintenance and damage, and spread toward the major county arterial highway, Marysville Road. The fuel break provided time to marshal firefighting resources. Quick access to the fire was also gained through the new road. The $\$ 52,500$ grant proved to be an investment that paid off many times over in helping to stop the fire. 


\section{Fire safe councils and UCCE}

The education and applied research activities that have occurred in these wildfire-prone counties illustrate the synergistic relationship between fire safe councils and UCCE. The fire safe councils play a vital role in the communities, alongside federal and state agencies and citizens concerned about forest health and safety. UCCE provides science-based forestry and wildfire information to help the councils fulfill their educational mission and, because of its extensive history in training and collaboration, UCCE presents the information in formats that raise awareness and enable effective pre-fire action. The partnership between the councils and UCCE optimizes the impact that both can have on wildfires in California. CA

G.A. Nader is UC Cooperative Extension (UCCE) Livestock and Natural Resources Advisor in Sutter, Yuba and Butte counties; and M. De Lasaux is UCCE Natural Resources Advisor in Plumas and Sierra counties.

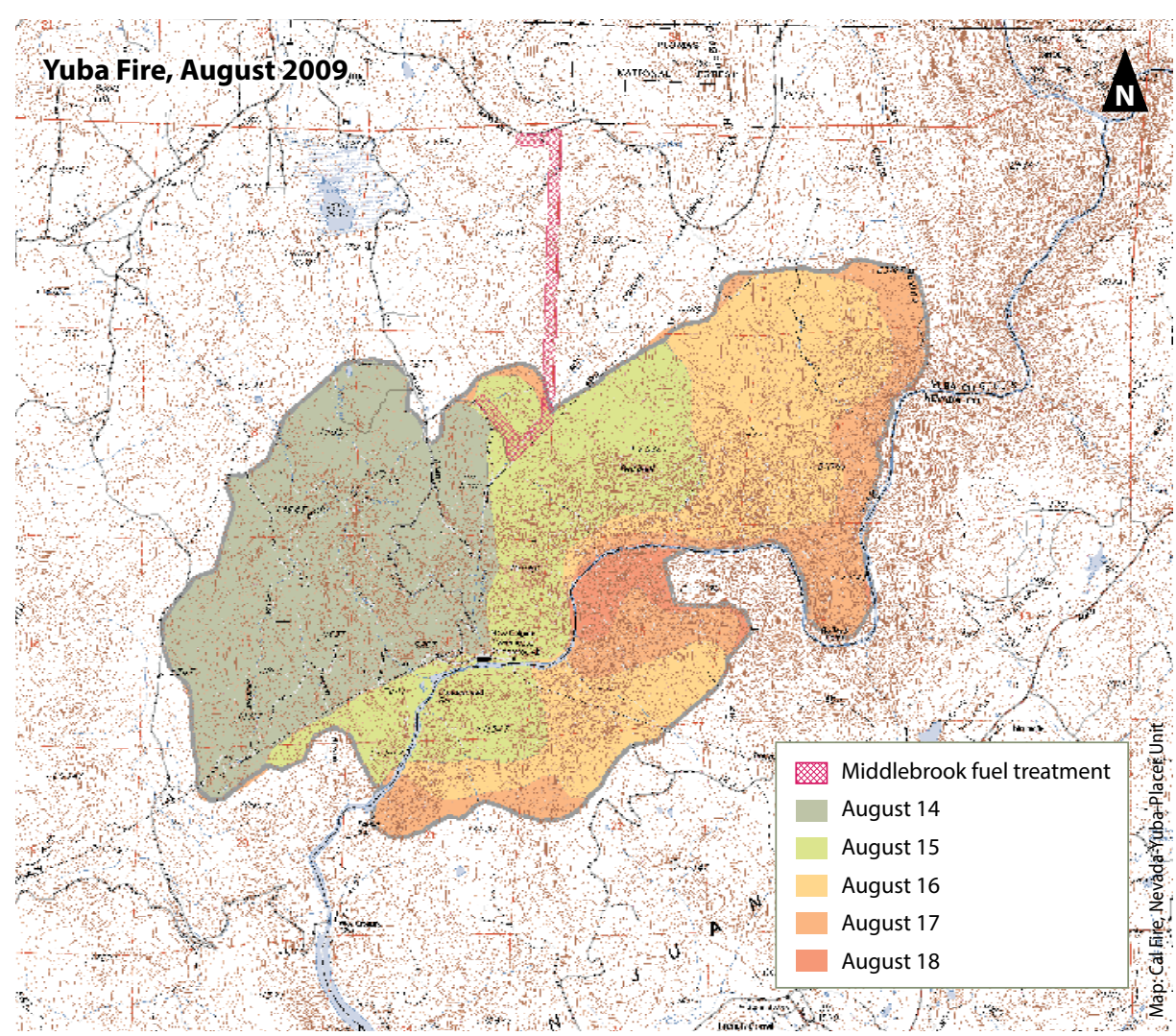

Fig. 7. Map of the Yuba fire.

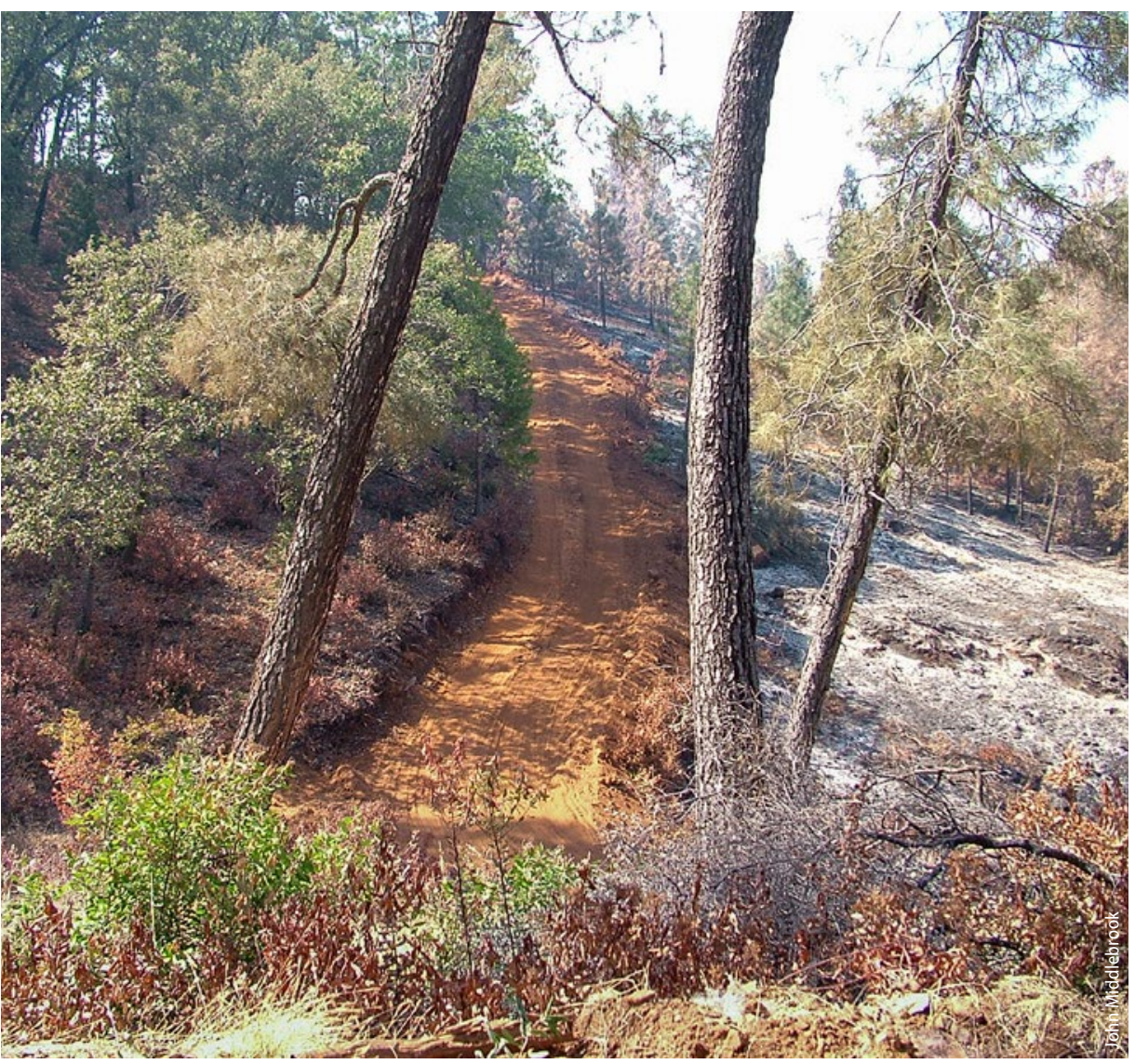

The Yuba fire stopped at the Middlebrook fuel break and access road.

\section{References}

Ballard HL, Evans ER. 2012. Wildfire in the Foothills: Youth Working with Communities to Adapt to Wildfire. Res. Note NRS-160. US Department of Agriculture, Forest Service, Northern Research Station, Newtown Square, PA. 14 p. www.nrs.fs.fed.us/pubs/ rn/rn_nrs160.pdf.

Chiono LA, O'Hara KL, De Lasaux MJ, et al. 2012. Development of vegetation and surface fuels following fire hazard reduction treatment. Forests 3(3):700-22.

Downey PO. 2000. Broom and fire: Management implications. Plant Protect Q 15:178-83.

McClintock E. 1985. Brooms. Fremontia 12:(4)11-5.

Nader G, Nakamura G, De Lasaux M. 2007. Home Landscaping for Fire. UC ANR Pub 8228. Oakland, CA. http://anrcatalog.ucdavis.edu/pdf/8228.pdf.

[NFPA] Nation Fire Protection Association. 1997. Standard for Protection of Life and Property From Wildfire. NFPA Pub 299. 1 Batterymarch Park, Quincy, MA. 17 p.

Quarles SL, Beall FC. 2002. Testing protocols and fire tests in support of the performance-based codes. In: Proc Cal Wildfire Conf, Oct. 10-12, 2001. Oakland, CA Tech Report 35.01.462, UC Forest Products Laboratory, Richmond, CA. p 64-73.

Quarles SL, Valachovic Y, Nakamura GM, et al. 2010. Home Survival in Wildfire-Prone Areas: Building Materials and Design Considerations. UC ANR Pub 8393. Oakland, CA. http://anrcatalog.ucdavis.edu/ pdf/8393.pdf.

Smith E. 1999. Living with Fire: A Guide for the Homeowner. University of Nevada Cooperative Extension, Reno, NV. 